\title{
The Nexus between Work-Life Conflict and Job Satisfaction: Evidence from Network and System Integration Industry in Sri Lanka
}

\author{
Nuwanthi Wijesekare $^{1}$ and Susima Weligamage ${ }^{2}$ \\ ${ }^{1,2}$ Department of Finance, University of Kelaniya, Sri Lanka \\ ${ }^{1}$ nuwanthiwijesekera@gmail.com, ${ }^{2}$ susima@kln.ac.lk
}

\begin{abstract}
Work life conflict is an inter role conflict that arises due to conflicting roles required by organization and from one's family. Objective of this study is to investigate the impact of work life conflict on job satisfaction of employees in Network and System Integration industry in Sri Lanka. Data for the study was from 147 employees working in different Network and System Integration organizations of Sri Lanka using structured questionnaire. Correlation analysis was used to find the association between identified variables of the study. Findings revealed that job satisfaction is significantly negatively correlated with Family to Work interference and Stress. However, the correlation of Work to Family Interference and working hours are positive and insignificant which shows that these two variables does not affect the job satisfaction of the employees in Network and System Integration Industry. The findings of the study suggest that work family conflict and job satisfaction becomes an increasingly important concern for organizations when focusing on the issue of developing employees in the changing global and regional scenario. Information Technology organizations should come up with effective and efficient work - life balance policies and programs and foster an organizational culture that supports the use of available policies is also of great importance. This will help to reduce the work - life conflict for employees in Network and System Integration Industry
\end{abstract}

Keywords: Work life conflict, Family to Work Interference, Job satisfaction, Stress, Network and System Integration Industry 


\section{Introduction}

The fast pace economic development in $20^{\text {th }}$ century, across the globe has created new endeavors for the business organizations and globalization has changed the world into a global (Nadeem \& Abbas, 2009). The business world is continuously changing due to the advances and developments in technology and innovations in technology can change the way business activities are performed. Information Technology (IT) has played an important role in business since the 1950s and the use of technology to reduce costs, improve operations, enhance customer service, and improve communications has progressed rapidly over the past four decades (Ghalia \& Rateb, 2010). Network and System integration Industry is playing a major role in turning IT innovations into competitive business applications. Currently, this business is mainly run in a vendor-type mode where system solutions are purchased from an integrator (Satzger, 2010).

Period of industrialization served as a fore runner to the work/family conflict that intensified in the subsequent year. The relationships, struggles, and conflicts between workers and employers and between families and the workplace grew in this era (Nadeem \& Abbas, 2009). A person plays different role in the span of life, which include roles from work (worker, employer) and non-work (father, spouse, friend, sibling, etc). Work Life Conflict exists when time and energy demands to satisfy one role make it difficult to participate in other. Work life conflict also defined "as push and pull between family and work responsibilities (Nadeem \& Abbas, 2009).

Work family conflict is a common problem faced by majority of employees and results in negative outcomes such as fatigue, absenteeism at work and turnover intentions. The working world has changed dramatically over the years. More people in the workforce are more educated; workers are left with higher expectations and about gaining fulfillment at work, and people are working longer hours.

Information Technology Industry is one of the largest services Industry in the World. Network and System Integration Industry is one of the sub parts of this industry. The Work life conflict becomes the problem for every industry. Employees are facing the problems of Work to family 
interference, Family to work Interference, Stress and working hours which arise Work life conflict and it will leads to the job dissatisfaction (Nadeem \& Abbas, 2009). The result of job dissatisfaction will be the low performance of employees and it will impact on organizational profit. So this research analyzed the impact of work life conflict on job satisfaction in Network and System Integration Industry.

\section{Literature Review}

Job satisfaction, as an outcome variable of work-family conflict, is defined as "a pleasurable or positive emotional state resulting from the appraisal of one's job" (Nancy, 2003). Many studies proved from their results that those employees who claim work-family conflict in their lives generally unsatisfied with their jobs. It means that there is a negative relationship between work-family conflict and job satisfaction. Many studies results justify that professional worker feel dissatisfied when there is interference between job actions and family issues (Pasewark \& Viator, 2006).

Work-life conflict is defined as "a form of inter-role conflict in which work and family demands are mutually incompatible, meeting demands of both the domains is difficult" (Higgins \& Lee, 1994). Greenhaus \& Beutell, (1985) Stated that work family conflict occur when contribution in work role creates problems in contribution of family role. He said that workfamily conflict could arise from tough time demands, stress originated in one role spillover to other role disturbing the quality of life, and behaviors that were appropriate in one domain but are considered as inappropriate in other domain. When demands from family and work were equally mismatched and meeting demands of one field created difficulties in meeting demands of other field, it led to work-family conflict (Aslam, 2011). Work Family Conflict (WFC) addresses the impact of work on the family. Family-work conflict (FWC) addresses the impact of the family on the work activities of the family member.

Traditionally, researchers (Higgins \& Lee, 1994) measured WFC unidirectional but now investigations try to look at how families can interfere with work. Thus (Greenhaus \& Beutell, 1985) suggest that in order to get accurate measure of WFC researchers must consider both directions. According to these researchers, there are three forms of WFC, i.e., time- 
based conflict, strain-based conflict, and behavior-based conflict. Stress is a situation which force a person to deviate from normal functioning due to the change in his/her psychological and/or physiological condition, such that the person is forced to deviate from normal functioning (Iqbal \& Wassim, 2012). As the direct mental reaction to job stress (Weiya, 2010), job satisfaction has close relation with job stress. Also it has direct impact on the employees turn over intention; job performance etc.

Nadeem \& Abbas (2009) in their research concluded that there is no significant relationship exists between job satisfaction and stress. Researchers further added that other factors like salary, organizational policies, satisfaction with supervisors are associated with job satisfaction and minimize the impact of stress. But the research that had conducted by Ismali, Yunus \& Yao (2009) concluded there is a negative relationship between stress and job satisfaction.

Empirical studies over a decade suggested that there is significance difference in the number of predictors for WFC for male and female employees. Male employees are also facing the dilemma of how to balance between work and family life. Recent research found that there is no statistically significant difference in priorities between men and women (Nadeem \& Abbas, 2009).

Parasuraman \& Simmers (2001) studied that how work and family role features affected work-family conflict. He also studied indicators of psychological well-being among males and females workers who are selfemployed or organizationally employed. In that study, employment type and gender were independent variables. They concluded that as compared to the organizational employees, self-employed employees enjoy more selfsufficiency, and flexible working hours which leads to more job involvement and job satisfaction however they also experience more worklife conflict and less family satisfaction.

According to the Aslam's study (2011), it shows that there a weak relationship between work-family conflict, family-work conflict and employee retention among public and private sector employees of Pakistan. (Nadeem \& Abbas, 2009) research regarding "The Impact of Work Life 
Conflict on Job Satisfactions of Employees in Pakistan" they found that job satisfaction is significantly negatively correlated with work to family interference and family to work interference. Job satisfaction is also found to be negatively related with stress in the research. However, the correlation of workload is positive and insignificant which shows that workload does not affect the job satisfaction of the employees in Pakistan.

The previous research on workload shows that the results are affected by social norms and cultural differences among the different countries. The research by (Jorge \& Heloisa, 2006) studied the workload at different countries in the European Union block. The results of Portugal and Denmark show a positive relationship between workload and job satisfaction.

Silver \& Frances (1994) suggested that increasing availability of flexible job, which women can adopt with families, may reconcile the conflict between work and family responsibilities. In addition, business needs have given birth to a good number of flexible employment opportunities that decrease costs and increase changes in labor needs (Silver \& Frances, 1994).

Numerous studies support the negative relationship between work-family conflict and job satisfaction (Ahmad \& Masood, 2011). Some researchers reported that work-family also effect other job related variables i.e. employee organizational commitment, job satisfaction and job turnover intention. Similarly, many studies results justify that professional worker feel dissatisfied when there is interference between job actions and family issues (Pasewark \& Viator, 2006).

According to the (Jorge \& Heloisa, 2006) research the job satisfaction is negatively related to working hours - that people with longer working hours would be less satisfied with their jobs than those working less hours. However, according to the contributions from Denmark and Portugal, there is a positive relationship between working hours and job satisfaction.

Employees who are aspire to play a bigger role in technology need to maintain a consistently high learning curve. With the constant innovation happening in this arena, it is not enough to be a good worker in the IT 
industry; one must keep updating technological skills. No other industry sees such significant changes in technology from time to time (Valk \& Srinivasan, 2011). The time required for professional development will have to come out of the personal time of the employees. Long working hours, unpredictable workloads and the constant pressure of updating skills all have a strong impact on the work family Conflicts IT Industry.

According to the study of Valk \& Srinivasan (2011), IT professionals can achieve the work family balance by setting priorities in their work and personal lives and by having support systems both at work, formally through HR policies and programmes, and informally through supervisor and co-worker support and at home.

The study that had conducted by Imam \& Qureshi (2011) found during their research survey that even perception of workload influences the mood of an employee and may also increase the work life conflict. Workload requires longer hours of time, and according to Greenhaus \& Beutell (1985), one form of conflict is time conflict. This time conflict is based on employee strain that can affect work and family life negatively. The second implication for manager is that if employees are not under workload but working in longer hours, it may also cause employee psychological strain and may disturb the family life and decrease the job performance of employee. The psychological strain also leads to high (Hofstede, 1984).

Parasuraman \& Simmers (2001) studied how work and family role features affected work-family conflict. He also studied indicators of psychological well-being among males and females workers who are self-employed or organizationally employed. In that study, employment type and gender were independent variables. They concluded that as compared to the organizational employees, self-employed employees enjoy more selfsufficiency, and flexible working hours which leads to more job involvement and job satisfaction. However, they also experience more work-life conflict and less family satisfaction. However, the research that had conducted by Anwar \& Shahzad, (2011) and concluded that there is no significant relationship between work-life conflict and employee perceived performance in Pakistan. The nature of effect of work-life conflict on 
perceived employee performance depends on environment and culture of the particular geographical region.

\section{Objectives of the Study}

The main objective of this research is to find whether there is an impact on work life conflict on job satisfaction in System Integration industry. The impact of work to family interference, Family to Work Interference, working hours and stress on job satisfaction.

\subsection{Specific Objectives:}

- To study the relationship between job satisfaction and work to family interference of employees in Network and System Integration industry in Sri Lanka.

- To study the relationship between job satisfaction and family to work interference of employees in Network and System Integration industry in Sri Lanka.

- To study the relationship between working hours and job satisfaction of employees in Network and System Integration industry in Sri Lanka.

- To study the relationship between stress and job satisfaction of employees in Network and System Integration industry in Sri Lanka.

\section{Methodology}

\subsection{Conceptual Framework}

Figure 01 presents the conceptual framework used in this study. The independent variables of the study are work life conflict (family to work interference, work to family interference) working hours and stress and Job satisfaction is the main dependent variable. 


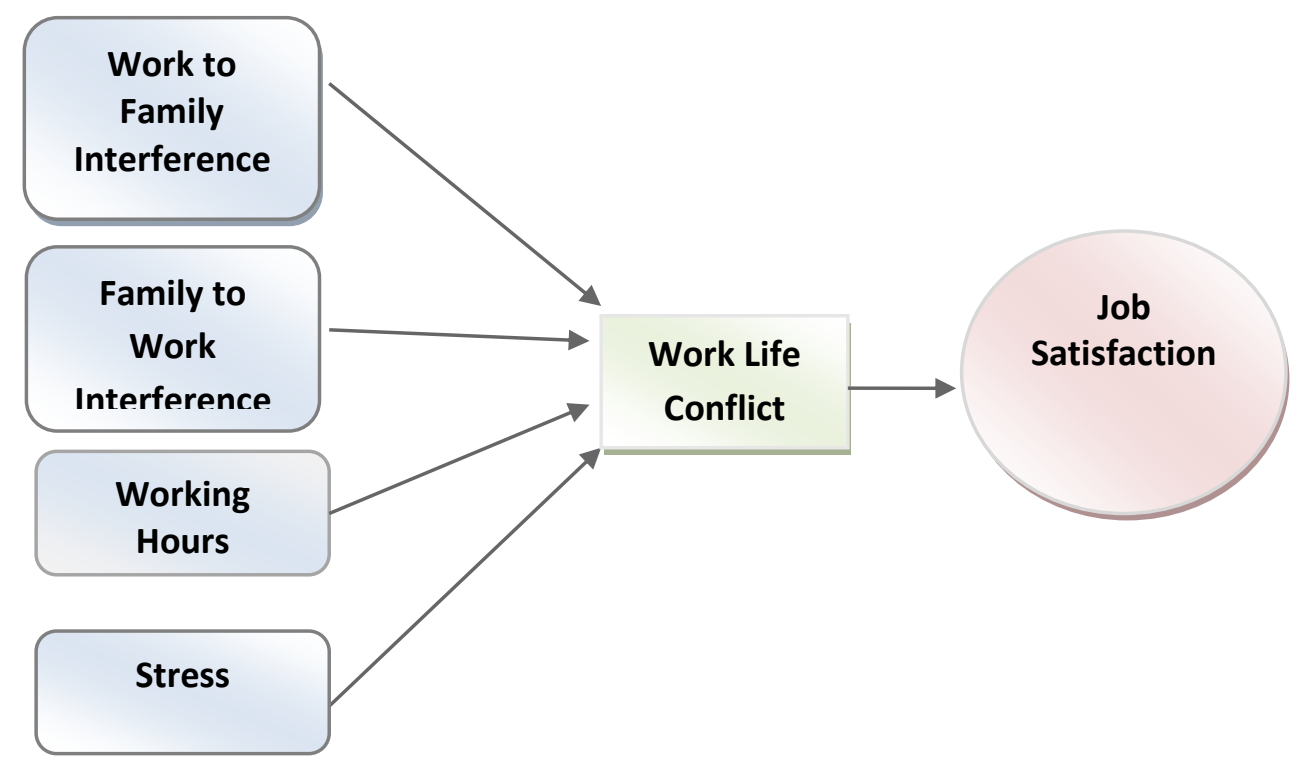

Figure 01: Conceptual Framework

\subsection{Hypotheses}

Hypothesis 1: There is a significant negative relationship between job satisfaction and Work to Family interference.

Hypothesis 2: There is a significant negative relationship between job satisfaction and Family to Work interference.

Hypothesis 3: There is a significant negative relationship between working hours and job satisfaction.

Hypothesis 4: There is a significant negative relationship between stress and job satisfaction.

\subsection{Population and the Sample}

A population for this research is the 200 employees who are working in Network and System Integration Industry. According to the Sri Lanka Business directory, there are 60 Network and System Integration Companies 
are available in Sri Lanka. Out of that 20, companies were selected for the research.

The sample for this research is the employees who are working in Network and System Integration Industry. Three categories are selected for this research. Senior Systems / Network Engineers, System /Network Engineers, Associated Systems / Network Engineers.

200 questionnaires were randomly distributed among Senior Systems / Network Engineers, System / Network Engineers and Associated Systems/Network Engineers of these organizations, responses from 147 questionnaires were received. Hence, the response rate was $73.5 \%$.

\subsection{Data Collection Methods}

Questioner method is used to collect the data and questionnaire consists of 6 major sections. First section was used to collect the general information about the employees. Second Section contains the questions to measure variable "work to family interference", next section uses to measure variable "family to work Interference" fourth section questions will measure variable "Working hours" Fifth section was used to measure the variable "Stress" and the sixth section in Questionnaire measures the Job Satisfaction. A Five point Likert scale was used to rate the responses ranging from $1=$ strongly disagree to $5=$ strongly agree.

\section{Data Analysis and Discussion}

The total number of respondents of the study is 147 , amongst them majority are males $(n=137)$ and as a percentage, it is $93 \%$. This is mainly due to the nature of the industry, where more employee opportunities are available for males. As per the industry, most of the employees are within 20-30 age. It is nearly $58 \%$ as a percentage, however, $39 \%$, and $8 \%$ of respondents were reported age $31-40$ and above 40 . The highest number of respondents of this study is married which is $65 \%$ of the total respondents. Table 1 presents the occupational status of the sample and Senior System Network Engineers, System Network Engineers and Associated System Network Engineers are about 17\%, $43 \%$ and $40 \%$ respectively. As per the sample of 
respondents, majority has more than 5 years' experience in the industry. However, total percentage of 3 years or above experience employees is $70 \%$ of the total respondents.

Table 01: Occupational Status

\begin{tabular}{|l|c|c|}
\hline \multicolumn{1}{|c|}{ Occupational Status } & Frequency & $\%$ \\
\hline Senior Systems/Network Engineers & 25 & 17.0 \\
System/Network Engineers & 64 & 43.5 \\
Associated Systems/Network Engineers & 58 & 39.5 \\
Total & 147 & 100.0 \\
\hline
\end{tabular}

Amongst total respondents, nearly 50\% of respondents are having minor dependents while it is reported $91 \%$ of employees are having elderly dependents.

\section{Table 02: Dependents}

\begin{tabular}{|c|l|c|l|l|}
\hline \multirow{2}{*}{ Dependents } & \multicolumn{2}{|c|}{ Minor Dependents } & \multicolumn{2}{c|}{ Elderly Dependents } \\
\cline { 2 - 5 } & Frequency & $\%$ & Frequency & \multicolumn{1}{c|}{$\%$} \\
\hline Yes & 73 & 49.7 & 134 & 91.2 \\
No & 74 & 50.3 & 13 & 8.8 \\
Total & 147 & 100.0 & 147 & 100.0 \\
\hline
\end{tabular}

In order to further prove the fact indicated by descriptive statistics, it was used one sample T-test. As per this technique, it is accepted that if mean value of a statement is greater than 3.5 and the $\mathrm{P}$ value of the T-test is significant, it was considered that the statement was accepted by respondents.

As per the below table, it is reported more than three values for the mean value. As per the feedback of the respondents they have agreed that their job is interfering their personal lives. In below table, significant level is less than 0.05 indicating that the mean values reported for statements are higher than 3 (neutral Level). Therefore, it is statistically proven that respondents have accepted the interference of work to family. 
Table 03: One-Sample Statistics and Sample Test

\begin{tabular}{|l|c|l|l|l|}
\hline & Mean & $\begin{array}{c}\text { Std. } \\
\text { Deviation }\end{array}$ & $\mathrm{T}$ & $\begin{array}{l}\text { Sig. (1- } \\
\text { tailed) }\end{array}$ \\
\hline WF -Work to Family Interference & 3.5510 & .52582 & 81.879 & .000 \\
FW -Total Family to work interference & 3.5510 & .52582 & 12.705 & .000 \\
S-Stress & 3.5374 & .51381 & 12.681 & .000 \\
WH-Working Hours & 3.7075 & .45647 & 18.791 & .000 \\
JS- Job Satisfaction & 3.0272 & .30846 & 1.070 & .002 \\
\hline
\end{tabular}

$(n=147)$

The all statements placed for measuring Family to work interference indicating that employees in the industry accepted that, there is a family to work interference. That is indicated by the mean value for total family to work interference reported 3.5 of mean value. Significance level in the above table for the statements reported less than 0.05 statistically indicating that respondents have accepted the fact that they are under the stress due to their job. The employee overall attitude on working hours reported 3.7 of mean value indicating that employees have accepted that they are having issues with their working hours.

This study was designed to measure the correlation between job satisfaction and some influential factors such as work to family interference, Family to work interference, working hours and employee stress level. Since, the questionnaire is included the pre-determined variables. It is used mean value of the statements used for measuring one variable to undertake correlation analysis. Pearson correlation analysis was conducted in order to measure the correlation between variables. The results as follows (table 4).

As per the output it is reported, that there are relationship between family to work interference and Job Satisfaction, and Employee Stress Level and Job Satisfaction. Due to the nature of Network and System Integration Industry, employees have to manage significant level of stress. Therefore, it is indicated that there is a negative correlation between employee stress level and employee job satisfaction. However, the correlation amongst those two variables has shown weak negative correlation. It is -0.179 . On the other 
hand, employees have shown there is a relationship between Family to Work interference and Employee job Satisfaction. The relationship was proven by the significance level, which is reported as 0.014 . The correlation between Family to Work interference and job satisfaction also has shown weak negative correlation which is -0.203 . If consider about the other two factors such as working hours and Work to family interference, those two factors have shown that there is no relationship with Job satisfaction.

As per the above results, for the hypothesis one (H1: There is a significant negative relationship between job satisfaction and Work to Family interference) it is reported more than 0.05 of $\mathrm{P}$ value indicating that there is no relationship between Work to Family interference in Network and System integration industry. Therefore null hypothesis is accepted. In hypothesis two ( $\mathrm{H} 2$ : There is a significant negative relationship between job satisfaction and Family to Work interference), it says that there is a relationship between employee job satisfaction and Family to Work influence. The $\mathrm{P}$ value for this is being reported as 0.014 indicating that there is a relationship between employee job satisfaction and the Family to Work interference. Therefore, the alternative hypothesis is accepted. 
Kelaniya Journal of Human Resource Management

Volume 09-Number 01-January 2014 \& Number 02-July 2014

Table 01: Correlations

\begin{tabular}{|c|c|c|c|c|c|c|}
\hline & & $\begin{array}{l}\text { Work to Family } \\
\text { Interference }\end{array}$ & $\begin{array}{l}\text { Family to } \\
\text { work } \\
\text { interference }\end{array}$ & Stress Level & $\begin{array}{c}\text { Working } \\
\text { Hours }\end{array}$ & $\begin{array}{c}\text { Job } \\
\text { Satisfaction }\end{array}$ \\
\hline \multirow[t]{3}{*}{$\begin{array}{l}\text { Work to Family } \\
\text { Interference }\end{array}$} & Pearson Correlation & & .004 & .026 & .035 & .059 \\
\hline & Sig. (1-tailed) & & .960 & .756 & .671 & .478 \\
\hline & $\mathrm{N}$ & 147 & 147 & 147 & 147 & 147 \\
\hline \multirow{3}{*}{$\begin{array}{l}\text { Family to work } \\
\text { interference }\end{array}$} & Pearson Correlation & .004 & & -.039 & -.066 & $-.203(*)$ \\
\hline & Sig. (1-tailed) & .960 & & .641 & .428 & .014 \\
\hline & $\mathrm{N}$ & 147 & 147 & 147 & 147 & 147 \\
\hline \multirow[t]{3}{*}{ Stress Level } & Pearson Correlation & .026 & -.039 & & .032 & $-.179(*)$ \\
\hline & Sig. (1-tailed) & .756 & .641 & & 697 & .030 \\
\hline & $\mathrm{N}$ & 147 & 147 & 147 & 147 & 147 \\
\hline \multirow[t]{3}{*}{ Working Hours } & Pearson Correlation & .035 & -.066 & .032 & & .106 \\
\hline & Sig. (1-tailed) & .671 & .428 & .697 & & .203 \\
\hline & $\mathrm{N}$ & 147 & 147 & 147 & 147 & 147 \\
\hline \multirow[t]{3}{*}{ Job Satisfaction } & Pearson Correlation & .059 & $-.203(*)$ & $-.179(*)$ & .106 & \\
\hline & Sig. (1-tailed) & .478 & .014 & .030 & .203 & \\
\hline & $\mathrm{N}$ & 147 & 147 & 147 & 147 & 147 \\
\hline
\end{tabular}

* Correlation is significant at the 0.05 level (1-tailed). 
Hypothesis three (H3: There is a significant negative relationship between working hours and job satisfaction) measured the relationship between employee job satisfaction and the employee working hours. The $\mathrm{P}$ value reported for this is more than 0.05 . Hence the null hypothesis is accepted. The null hypothesis says that there is no relationship between employee job satisfaction and the employee working hours. The hypothesis four (There is a negative relationship between stress and job satisfaction) measures the relationship between employee job satisfaction and the employee stress level. The $\mathrm{P}$ value for this statement is reported as 0.030 . That has proven that there is a relationship between employee job satisfaction and the employee stress level.

The factor analysis was conducted to understand the components (variables) that are explained by the sample. The adequacy level of the factor analysis was tested by using the KMO and Bartlett's test. As per this test, to accept the sample KMO value should be more than 0.5 . Therefore, the table 5 shows the adequacy level of 0.521 indicating that the data set use for the factor analysis is adequate for the factor analysis.

\section{Table 05: KMO and Bartlett's Test}

\begin{tabular}{|l|r|}
\hline \multicolumn{2}{|l|}{ Kaiser-Meyer-Olkin Measure of Sampling } \\
Adequacy.
\end{tabular}

Source: Survey Data, 2015

Based on the factor loadings value, components with more than 0.5 were categorized as one factor. Therefore the following factors were identified based on factor analysis results as factors that represent issues relating to work life of employees who are working on Network and system integration industry. 
Factor 01: Stress due to family Responsibilities

Factor 02: Work to Family interference

Factor 03: Working Overtime

Factor 04: Appropriateness of working hours

Factor 05: Family influence on working extended hours for

Factor 06: Family pressure

Factor 07: Anxiousness

Factor 08: Conflict of family and work interest

Factor 09: Interference of spouse on work related activities

\section{Conclusion}

The tested variables of this study are the Family to work interference, work to family interference, Stress and the working hours. As per the mean values reported for statements used for measuring employee attitude, it is reported that most of the employees in the industry have negative attitudes on their jobs with regards to the Work to family interference, Family to work interference, Stress and Working hours. It is reflected that employee dissatisfaction occurs mainly due to pressure coming from family related responsibilities.

It is found that there is a weak negative relationship between employee Job satisfaction and the Family to Work interference and the employee stress. Furthermore, based on the factor analysis conducted for identifying factors of employee work life satisfaction, it is found that eight factors represents the issues related to working place such as Stress due to family responsibilities, Work to family interference, Working overtime, Appropriateness of the working hour arrangements, Family Pressure, Anxiousness, Conflicts of work and family interests, Spouse or Family interference. The results of the study are important for the researchers which they can consider the results as a guideline for further research especially in the same region.

Whether it is a male employee or female, he/she has to take care of the family, career and social setups prevailing in the society. All areas are very important in a life. So, it is the responsibility of the organizations to provide them a comfortable work environment in which the employees feel free and perform to the maximum that leads to organizational better performance. 
Managing both professional and personal life effectively and efficiently has become a major challenge for the employees Network and system Integration Industry. IT organizations need to develop effective work -life balance policies and encourage their employees to make use of the available policies. This will help increase organizational commitment, improve productivity, efficiency, retain best talent and motivate the employees to give their best.

Also organizations can implement various interventions such as family friendly policies, Stress Management programmes and flexible working hours so as to minimize work family conflict and to provide intrinsic and extrinsic rewards to maximize job satisfaction. Organizations should clearly define the roles and responsibilities for each every employee so that there is a clear objective laid down by the organization as to who is accountable for what and no does extra work. By doing this, organizations will help to reduce the stress.

\section{References}

Ahmad. M, \& Masood. M. (2011). Work Family Conflict among Women University Teachers-A Case from Pakistan . European Journal of Social Sciences - , 2, 119-130.

Anwar. M, \& Shahzad. K. (2011). Impact of Work-Life Conflict on Perceived Employee. European Journal of Economics, Finance and Administrative Sciences , 82-86.

Aslam, S. (2011). Work family conflicts :Relationship between Work-life conflict and employee retention. Interdisiplinary Jornal of research in bussiness, 1, 18-29.

Ghalia. A, \& Rateb. J. (2010). The relationship between Information Technology adaption and job satisfaction in contracting companies in jordan. Information Technology in construction , 15, 44-63.

Greenhaus. J, \& Beutell.N. (1985). Sources of Conflict between work and family roles. Academy of Management Review, 76-88. 
Higgins. C. \& Lee. C. D. (1994). Impact of life-Cycle stage and gender on the ability to Balance Work and Family Responsibilities. Pakistan Journal of Social and Clinical Psychology, 144-150.

Hofstede.G. (1984). The Cultural Relativity of the Quality Of Life Concept. Academy of Management Review , 9, 389-398.

Imam.H, \& Qureshi.T, K. (2011). The retrenchment effect on job performance with mediating effect of work life balance. African Journal of Business Management , 5, 8642-8648.

Iqbal. M, \& Wassim. M. (2012). Impact of Job Stress on Job Satisfaction among Air Traffic Controllers of Civil Aviation Authority: An Empirical Study from Pakistan. International Journal of Human Resource Studies , 2, 53-70.

Ismali.A, Yunus.K, \& Yao.A. (2009). Relationship Between Occupational Stress and Job Satisfaction:An Empirical Study. The Romanian Economic Journal , 3-29.

Jorge.C, \& Heloisa.P. (2006). Measuring job satisfaction in surveys Comparative analytical report. European Foundation for the Improvement of Living and Working Conditions , 2-30.

Nadeem.M, \& Abbas.Q. (2009). The impact of work life conflict on job satsfaction of employees in Pakistan. International jouranal of bussiness and management , 4, 63-83.

Nancy.L. (2003, June). Work/Life Balance: Challenges and Solution. HR Magazine.

Parasuraman.S, \& Simmers.C. (2001). Type of Employment, Work-Family Conflict and Well-Being:A Comparative Study. Journal of Organizational Behavior , 5, 551-568.

Pasewark.W, \& Viator.R. (2006). Sources of work-family conflict in the accounting profession. Behavioral Research in Accounting , 147-165.

Satzger, G. (2010). System Integration in Information Technology - An Intermediation Rather Than a Procurement Task? Finance \& Information Management, 2-14. 
Kelaniya Journal of Human Resource Management

Volume 09-Number 01-January 2014 \& Number 02-July 2014

Silver, H. \& Frances, G. (1994). Flexible Work and Housework: Work and Family Constraints on Women's Domestic Labor. 1103-1119.

Valk, R. \& Srinivasan,V. (2011). Workefamily balance of Indian women software professionals: A qualitative study. Science Direct, 39-50.

Weiya, Y. (2010). An Emperical study on Relationship between Job stress and Job satisfaction of First-Line employees in Mediuem-small private enterprises in China. School of Bussiness. 